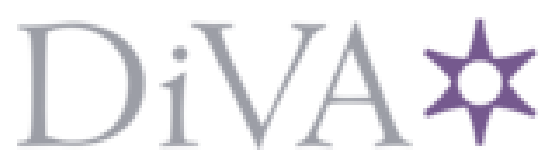

http://www.diva-portal.org

This is the published version of a chapter published in International Handbook on Giftedness.

Citation for the original published chapter:

Persson, R. (2009)

The Elusive Muse: Understanding Musical Giftedness.

In: Larisa V. Shavinina (ed.), International Handbook on Giftedness (pp. 727-749). Dordrecht: Springer Science

N.B. When citing this work, cite the original published chapter.

Permanent link to this version:

http://urn.kb.se/resolve?urn=urn:nbn:se:hj:diva-7269 


\title{
Chapter 36
}

\section{The Elusive Muse: Understanding Musical Giftedness}

\author{
Roland S. Persson
}

\begin{abstract}
Many labels exist to outline musical giftedness or aspects of it; a profusion resulting from different epistemological positions, disagreements, and the considerable complexity of the issue. In this chapter, musical giftedness as a sub-cultural attribute is discussed as well as the problems inherent in attribution by consensus procedures. Based on available research a conceptual model of musical giftedness is outlined based on domain generality and domain specificity, thus proposing an understanding of musical giftedness as a set of core skills and sets of key skills, particular for specific domains. The question of heredity is brought to the fore as is the significance of accumulated practice over time. Differences between the development of Western Classical musicians and popular musicians are demonstrated. Recent research on giftedness identification is also discussed followed by a concluding overview of potential research pitfalls as the understanding of musical giftedness continues to be explored.
\end{abstract}

Keywords Musical giftedness - Musical talent $\cdot \mathrm{Mu}-$ sical capacity - Musical intelligence - Domain generality - Domain specificity - Heredity - Genotypes · Phenotypes

\section{Making Sense of Nomenclature}

Any effort to define musical giftedness must first deal with nomenclature. An individual superior than

R.S. Persson $(\bowtie)$

Jönköping University, Jönköping, Sweden

e-mail: roland.persson@hlk.hj.se a majority of others in one or more musical domains has prompted the use of a number of different labels, often used quite loosely in the literature. This is also true, to some extent, of giftedness research and gifted education in general (cf. Gagné, 1985; Ziegler \& Raul, 2000). The many available labels reflect not only differing epistemological worldviews but most certainly also disagreements and the considerable complexity of the matter at hand. However, I propose that many of these labels can be more or less subsumed under either genotype (genetically determined potential) or phenotype (the developed and observable behavior resulting from a certain genotype). In addition, there are also terms in use, which comprise every musical activity or aspect of musical behavior (see Table 36.1). While nomenclature relating to either genotype or phenotype is usually scientific, the all-inclusive terms are more commonly used outside the world of science.

\section{Genotype Labels}

Among labels proposed as more or less genotypes in nature are musical aptitude, musical capacity, and musical intelligence. Aptitude for music is considered to consist of one general or several fundamental cognitive skills, which can all in various ways be identified by standardized tests (Shuter-Dyson \& Gabriel, 1981; Shuter-Dyson, 1982). It has been suggested by Gordon (1995) that musical aptitude has a qualitatively different basis than nonmusical aptitudes. He terms this basis audiation, which is "to hear and to comprehend music for which the sound is no longer or never has been present. Audiation is to music what thinking is to 
Table 36.1 The variety of labels used in the literature of musical behavior

\begin{tabular}{cll}
\hline Genotype & Phenotype & All-inclusive terms \\
\hline $\begin{array}{c}\text { Musical } \\
\text { aptitude } \\
\begin{array}{c}\text { Musical } \\
\text { capacity }\end{array}\end{array}$ & Musical talent & To be musical \\
$\begin{array}{c}\text { Musical intel- } \\
\text { ligence }\end{array}$ & $\begin{array}{l}\text { Musical achievement } \\
\text { Creative musical talent }\end{array}$ & \\
& $\begin{array}{l}\text { Musical expertise } \\
\text { Musical excellence }\end{array}$ \\
& Musical eminence & \\
& Musical elite talent & \\
& Musical genius & \\
& Musical competence & \\
\hline
\end{tabular}

language" (p. 173). Audiation as a term, however, is not widely spread or used. To speak more generally of musical and the mind, which several researchers prefer, then "the musical mind" seems a more user-friendly term (Bamberger, 1991; Sloboda, 1985; Storr, 1992). Musical capacity is used interchangeably with aptitude in the literature. Musical intelligence, however, is a more recent expression (e.g., Bamberger, 1991). Arguing that music is an intelligence proper may well be a valid claim per se (Gardner, 1983), but it is my observation that the popularity of the term has spread worldwide for other reasons than the theoretical appropriateness of the term. Music has been declared a panacea of sorts for being effective both in therapeutic intervention and as a means to boost cognitive efficiency. While music as therapy in various ways has won considerable recognition in the scientific community a well as in medical practice (e.g., Bunt, 1994; Unkefer, 1990), music as having somehow "magical" effects on cognitive functions - particularly spatial task performanceis much more controversial. The so-called Mozart Effect (Campbell, 2001; Rauscher, Shaw, \& Ky, 1993; Tomatis, 1991) whereby listening to music, especially that of Mozart, allegedly raises short-term IQ, is hotly debated (Bruer, 2002) and often even declared a dubious, if not invalid, claim (Chabris, 1999; McKelvie \& Low, 2002; Steele, Bass, \& Crook, 1999). In the wake of this debate there arose an interest among educators whether music could in fact help improve achievement in other subjects more academic in nature. Consistent with findings that more or less undermine the Mozart Effect, the specific influence of music and art on more general achievement in educational settings has often also proven dubious or at the very least difficult to substantiate (Eisner, 1998). However, Winner \& Hetland (2000) having evaluated much of this line of research take middle ground. They argue that there is indeed evidence of causal links between, for example, music and spatial-temporal reasoning and learning to play music and spatial reasoning, and between classroom drama and verbal skills. But that there are no evidence of, and therefore no causal links, between arts education and verbal and mathematics scores/grades; art education and creative thinking; learning to play music and mathematics; learning to play music and reading; visual arts and reading; dance and reading; dance and nonverbal reasoning.

In this light, claiming that music is an intelligence provides music and art education with potential negotiation power in trying to fit the arts into a rationalist and technocratic social context, where the arts as profit and achievement enhancers would turn them into something more than "merely" being esthetical. In Winner \& Hetland's (2001) words: "Let's stop requiring more of the arts than of other subjects. The arts are the only school subjects that have been challenged to transfer as a justification for their usefulness ... Anyone who looks closely as we have done will see that these claims do not hold up unequivocally ... The arts are a fundamentally important part of culture, and an education without them is an impoverished education leading to an impoverished society" (p. 5).

\section{Phenotype Labels}

Among the phenotype labels are musical talent (Evans, Bickel, \& Pendarvis, 2000; Freeman, 1984; Haroutounian, 2002) and musical ability (Coon \& Carey, 1989; Shuter-Dyson, 1982; Howe, Davidson, Moore \& Sloboda, 1995), both of which are also used interchangeably in the literature. However, they always refer to a manifest set of cognitive skills such as memory, aural discriminatory skills, and motor skills; skills that are assumed to be necessary for musical achievement, which is another term used in this context, the connotation of which is that which musicians have learnt on the basis of their aptitude (Shuter-Dyson, 1982). Creative musical ability, however, has a more specific use. Most often it refers to composing, improvising or arranging music (Brenneis, 1990; Piirto, 1992; Haroutounian, 2002). Note that while Jazz musicians 
are expected to be creative in various ways as they perform (Andreas, 1993; Kenny \& Gellrich, 2002; Pressing, 1988) the same is not typically true of Western Classical musicians found performing in concert halls all over the world. They do not normally exceed the general norm for how a certain piece of music is to be played (Persson, 1993, 2000, 2004). To play "authentically" means that the score, the interpretational markings added by the composer, and the believed style of playing typical of a certain era constitute the more or less absolute norm (e.g., Haskell, 1988). A typical concert pianist, for example, pursues "reproductive art" and is not creative-at least not when performing the traditional repertoire (Polony, 1995).

Also among the phenotype labels are, I suggest, expertise (Sloboda, 1991; Ericsson, Krampe, \& TeschRömer, 1993; Sternberg, 2000; Ericsson, Nandagopal \& Roring, this volume) and excellence (Krampe \& Ericsson, 1996; Sloboda \& Howe, 1991; Trost, 2000), which are terms that are being increasingly used in reference to giftedness. However, they represent an entirely different research tradition that, unlike other traditions, does not usually view genetic potential as crucial in developing musical skills. It is rather argued that there are environmental factors that play a significant role and that virtually any skill, honed extensively and more systematically in comparison to an average person may, under more or less optimal circumstances, develop from novice to expert within a period of about 10 years - prompting the use of the so-called 10-year rule (Simon \& Chase, 1973; Simonton, 1992). In this research context scientists on occasion also use musical eminence (Barret, 2006; Simonton, 1989), which is "much more than mere recognition" (Albert, 1992, p. xvii). Eminence has a lasting impact on the social context, and redefines or changes understandings, styles, or, even to a degree, history itself. Subotnik $(2000,2003)$ has recently added a further dimension to this array of music phenotype labels as a result of studying extreme talent at the Juilliard School of Music, New York. Beyond expertise, she suggests, comes elite talent. One might argue perhaps that elite talent-an extreme form of giftedness-is an important prerequisite of becoming eminent and that elite talent is the same as the nowadays rarely used term genius (e.g., Kivy \& Ky, 2002).

Furthermore, the term musical competence (De la Motte-Haber, 1985; Deliège \& Sloboda, 1996) is also found in the literature. Although all-inclusive it tends to be used somewhat loosely as well. It is originally a social-psychological construct representing selfefficacy: the inherent human desire to perceive oneself as able (Sternberg \& Kolligian, 1990). Observe, however, that competence is a social construct in that a musician's experienced competence is also the result of acknowledged ability by the surrounding social context (Bandura, 1990). We are therefore generally motivated to strive to feel competent by striving also to be recognized as able or even highly able. Musicians are of course, for a variety of reasons (Persson, Pratt, \& Robson, 1992), motivated to achieve, to gain, and to sustain competence in their field of pursuit (O'Neil \& McPherson, 2002).

Finally, in use to describe human musical behavior are of course to be musical and musicality or, by implication, to be "unmusical." These are all-inclusive terms comprising the ability (or inability) to play, sing, compose, and to appreciate music and so on (Revesz, 1953; Zuckerkandl, 1973).

In the following discussion the term musical giftedness will be used when referring to individuals who for any possible reason appear "more musical" than most others; they learn musical structures quicker, have better memory for music, more easily discriminate tonal and rhythmic patterns, are more expressive, more emotionally attuned to music, and more sensitive to timbre and, depending on type of musical skill, also have a propensity for efficient motor learning that surpasses a majority of other individuals and so on. Implicit in the term is also social recognition for market profit, which might not be an issue early in a musician's development but certainly becomes an issue as they make music performance their profession. Musical giftedness is in a sense all-inclusive as a term also, but it is here intended to integrate the knowledge of different research traditions without taking an extreme epistemological stance. The nature of musical giftedness will be discussed in greater detail further on and a conceptual model of the nature of musical giftedness will be proposed.

\section{The Difficulties in Defining Musical Giftedness}

It is obvious from the variety of labels that are in use to describe musical behavior that there is both contention, 
perhaps also some confusion, what musical giftedness should be considered as. Music, after all, and its understanding as a cultural phenomenon has been the focus of scrutiny by philosophers, scientists, and mystics of different traditions, convictions and insights for very a long time.

One of the major controversies in defining musical giftedness, at least in modern times, regards whether one general capacity or several separate and more or less independent capacities underlie music as human behavior; which of course reflects the similar controversy regarding the nature of human intelligence (see Dennis \& Tapfield, 1996; Howe, 1997). Seashore (1938), for example, one of the pioneers in studying music behavior, recognized musical ability as complex. He argued for several, more or less independent, specific abilities. Others like Wing (1941) would rather understand music as one general cognitive function; a notion which has fairly recently been echoed also in proposing that the human capacity for music is, in fact, not only a single general function but even a specific intelligence inclusive of all behaviors musical (Gardner, 1983).

Most likely both positions have merit. Music behavior is both something general and something specific. However, before suggesting what dimensions may be missing in early attempts to identify musical giftedness, and make an effort to actually understand what the complex nature of musical giftedness could be, there are other confounding issues relating to the attribution of talent that need to be addressed.

\section{Musical Giftedness as a Sub-cultural Attribute}

Research into musical giftedness has almost exclusively been pursued in one sub-cultural setting only, namely that of Western Classical Music. This leaves giftedness with regard to other cultures' music and musical expressions virtually unaccounted for. Musical giftedness - or as termed by most of the labels listed in Table 36.1 above-is therefore unavoidably a limited, if not ethnocentrically biased, attribute (cf. Triandis, 1990). In Europe, North America, Australia, Japan, and other countries cherishing a Western classical music legacy, a concert pianist or opera singer would be more likely to be regarded and talked about as excep- tionally gifted rather than well-known popular music groups or artists such as Motörhead, Deep Purple, Judas Priest, U2, KISS, Backstreet Boys, Rammstein, ABBA, NSYNC, or Country and Western stars like Garth Brooks, Johnny Cash, and Dolly Parton, just to take a few random examples from different genres of Western music. Needless to say, these have all been recognized as gifted but not by researchers or music educators. Boyd \& George-Warren (1992) discovered when they interviewed 75 contemporary and popular musicians, all of whom have made a name for themselves, that a few wanted to start out learning a formal and basic Western classical music skill to help realizing their dreams in another genre. Their classically trained teachers, however, did certainly not recognize them as gifted. On the contrary, they would not accept them at all, and sometimes even punished any effort to be unique and deviate from claimed Western classical music norms. Further formal music teaching became an obstacle to these popular musicians' goals and dreams. They left formal education in music to learn on their own and were in the end identified as talented by market agents instead.

In contrast to the gifted Western Classical musicians, popular musicians are much more likely to be identified by their listeners, their marketing agents, or by so-called talent search companies. Once identified they may be on their of way turning into "superstars." The nature of the giftedness definition then becomes entirely different from that so far proposed by educators and psychologists: He or she who has the greatest potential to generate profit has "talent"-quite irrespective of any attention to cognitive attributes and environmental precursors to excellence. They may even reach superstardom; a phenomenon which, according to Rosen (1981), is argued to exist "when relatively small numbers of people earn enormous amounts of money and seem to dominate the fields in which they engage" (p. 849) and furthermore "small differences in talent become magnified in larger earnings differences with greater magnification of the earnings-talent gradient increases sharply near the top of the scale" (p. 846). Although this argued relationship between degree of talent and differences between talents and record sales is not clear (Adler, 1985; Hamlen, 1991), it nevertheless demonstrates the considerable interest of the market to search for talent in, for example, popular music. Needless to say the possibility of fame has attraction to many (Braudy, 1997). Would-be superstars also seek 
out talent search companies of which, in time of writing this, the concept of "American Idol" and its many spin-off TV productions in 100 different countries is a very good example (e.g., Martin, 2006; or the original website at http://www.americanidol.com). The idea is that anyone who is convinced of their own potential as a future pop star can come to advertised and scheduled auditions where a screening takes place in front of a jury of already famed and established artists and representatives of the music industry. Jurors' deliberations and assessments, especially of participants who fail to win the jury's approval, in a somewhat ethically doubtful way, become a major "entertainment value." In the end a handful potential superstars remain. One is voted winner and receives professional assistance to launch a career as superstar.

In order to more fully understand the notion of musical giftedness science cannot afford to be subculturally biased in this way and use as a research sample musicians from one type of context only-not for as long as we argue there is only one type of musical giftedness. Such a research sample would be unacceptable in almost any other kind of research if the desire is to generalize results. Therefore, it is appropriate to argue that we know only to some degree what musical giftedness is and that this knowledge is in a sense domain specific in that it relates to Western Classical music almost exclusively. We know much less how musical giftedness is constituted and manifested in other cultures and sub-cultures.

Hence, any further study of musical giftedness as a general phenomenon will need to extend samples to include representatives of other cultures, sub-cultures, and genres too. Also the social reality of being gifted in music, especially when making it a professional career, needs to be considered and included. In a market economy giftedness becomes a commodity and someone's talent is assessed in accordance with their potential to generate profit. Probably three lines of research need to be made distinct: (1) Music ability as domain generality (the question of genotype); (2) musical activities as domain-specific research per sub-culture or culture; perhaps even per musical instrument (the question of phenotype); and also (3) the social dynamics of being musically gifted, which to an extent could be understood as "success or failure in the light of supply and demand." That which we crave sells, whereas that which we do not want-for various reasons-will have no attraction whatsoever irrespective of an indi- vidual's objective status of giftedness (see Subotnik, Jarvin, Moga, \& Sternberg, 2004; Persson, 2006). This is also to some extent the direction that, for example, research on creativity is taking: "Creativity," say Lubart \& Guignard (2004), "is partly generalized ability, partly a set of domain specific abilities, and partly a set of task-specific abilities" (p. 43).

\section{The Ambiguity of Social Consensus}

Focusing on the notion of domain-specific giftedness in the Western classical tradition, there is yet another confounding issue in defining what musical giftedness means. To be identified as more or less gifted in musical performance (instrument or voice) is often made by a consensus procedure. When prospective students seek admission to an institution for higher learning auditions usually play an important role. Students are asked to perform in front of a jury. The ones considered — by deliberation and sometimes also by vote- the most talented and promising are accepted to the applied-for program at the conservatory or at the department of music where the student wishes to study. The same principle applies at a music contest: a jury listens to all the contestants. A selection is made by deliberations with the objective to identify the most promising ones, who will be allowed to proceed to a second round. In the end the jury nominates a winner. On rare occasions there will perhaps be a tie between two contestants, if jurors cannot reach consensus on who out of two contestants considered the best should win.

One could argue that the appointed winner is the most gifted one. He or she has been evaluated thoroughly in a competitive setting and found to be the most promising performer for the future. However, in a consensus procedure subjective preferences come into play and who should win or be admitted to a program is often decided on the basis of a compromisewhat the majority of jurors decide. Unless of course the jury is unanimous, which is not likely to happen often. Thompson \& Waterman (1990) report the many contentions that have taken place in juries at the The Leed's Piano Competition over the years:

...celebrated pianists though they confer star status on a competition, are not guaranteed to be good judges. Many great pianists are great out of fierce single-mindedness. 


\begin{abstract}
Some great pianists only admire the qualities reflected in their own playing. And cannot empathize with other points of view ... The kind of college professor who tends to appear on juries now are looking for a certain kind of academic correctness. They should be looking for attributes way beyond that - for that quality of revelation, wonder, magic, that indefinable special something, apprehended but not comprehended, something which is beyond technique (pp. 109-110).
\end{abstract}

Bastian (1987) reports in his study of competitions for young gifted musicians in Germany that jurors sometimes have personal biases too when ranking one contestant higher than another. This makes an interesting comparison to Kingsbury's (1988) unique study of the social dynamics of an American, well-respected, music conservatory. He found that students were usually attributed with talent not necessarily according to what they actually did on stage performing but according to which teacher they studied with. The more famed the teacher the more talented his or her students were considered. Thus, inherent in the Western Classical music sub-culture is also a complex pattern of biases.

While it is argued by some that aesthetic quality certainly may be assessed successfully by consensus of experts (Elliot, 1987; Machotka, 1982; Mills, 1987), the procedure makes identification or ranking unreliable for at least research purposes when in search of "gifted performance" or any creative product for that matter, the reason being that jurors base their assessments on different criteria. Therefore, their understanding of giftedness by necessity also differs. That which is performance excellence to one juror is not necessarily excellence in the eyes of another. It has been known for some time that individuals vary in how they appreciate art and music. Music preference has been studied fairly extensively and several typologies have been developed (e.g., Hargreaves, 1986; Hedden, 1973; Persson, 1993; Wing, 1941). While it is simplistic to regard one's attitude to music as a dichotomous dimension between affective and analytic only (Hargreaves, 1986), such a simplistic dichotomy nevertheless serves well in demonstrating the opposing views in a music contest jury. They, too, have preferences according to which they evaluate a performance. Not infrequently do jurors, and Western Classical musicians in general, actually adopt dichotomous terms such as "academic, technical, intellectual" and use these as opposites to being "magical, emotional, artistic" in order to evaluate what they have just heard (cf. Dubal, 1985). Bastian (1987), for example, refers to contest performances being ei- ther "technical, artistic, or a show-off circus act void of artistry." While most Western classical musicians would agree on how to define at least some key aspects of musical giftedness (cf. Roberts, 1990; Subotnik et al., 2004; see also Subotnik this volume), they would most certainly disagree on which performance was the "best", if all were presented with a number of performers playing the same piece of music, as was clearly demonstrated in a study by Persson (1993).

\section{The Multi-dimensionality of Musical Giftedness}

The following discussion endeavors to understand what musical giftedness is as based on available research. However, in so doing I will venture to propose a conceptual model. The empirical knowledge available has to my knowledge so far not been brought together in a synthesis, but rather musical giftedness has been explored within the boundaries of different research traditions. The result, as shown earlier in this chapter, has certainly been one of promising beginnings but also one of some confusion since researchers have taken more or less an "either/or stance" on music as a general ability or as several specific and separate abilities; and the fact that educators, musicians, and others tend to use labels given to various aspects of the music phenomenon differently. The expertise research tradition avoids the use of giftedness as a term altogether and has introduced the notion of expertise as an alternative.

It is my contention that in addition to a human general capacity for music there are also a variety of $\operatorname{cog}$ nitive, affective, and social aspects, the numbers and significance of which vary with the social context in which musical skills develop. These aspects are not necessarily acoustical in nature. There is undeniably also a subjective dimension to music, which as far as I know no objective test of musical potential takes into consideration. This subjective dimension-termed $\mathrm{mu}$ sical reality by Persson $(1993,2001)$ - has become the focus of systematic empirical research only in recent years (Juslin \& Sloboda, 2001). That there exists an obvious relationship between musical expression and emotional experiences-irrespective of musical genre and context-has been known since Antiquity (e.g., Strunk, 1965). Presumably also for as long as music 
has been known to mankind, often in a religious context (Rouget, 1985). However, while musicians' subjective reality is real and very tangible to them and their educators (e.g., Juslin, 2001; Gabrielsson, 2001; Simonton, 2001), how it relates to the notion of giftedness requires further research, but because of its phenomenological significance it must nevertheless be part of a conceptual model.

Such a model of musical giftedness rests on a series of feasible assumptions, some of which are the direct results of research and others that are in need of research though their feasibility is at the very least implicated in the already existing body of empirical knowledge. In regard to the model discussed in the following, the assumptions concerning musical giftedness are (cf. Simonton, 1999; Oerter, 2003):

- Musical giftedness needs to be understood in terms of core skills common to all domains in which giftedness is to be studied or identified.

- Musical giftedness needs to be understood in terms of key skills specific to particular musical domains.

- Musical giftedness is dependent on heredity, but biologically determined potential must be stimulated and allowed to develop in a suitable environment to manifest.

- The nature of stimulation and development differs between musical domains.

- Everyone has musical capacity unless there is a neurological dysfunction. But everyone is not, nor can they become, musically gifted.

- Lack of individual and developed musical skill is not to be equaled to being void of musical capacity.

- Extensive practice of skills is the only means to develop a gifted individual to mastery of those skills thereby reaching full potential.

- Identification of musical giftedness is threedimensional: (1) objective and generalizable, (2) subjective and individual, and (3) social as based on estimated value or appreciation in a context of supply and demand.

\section{The Core Skills of Musical Giftedness}

To find an exact and commonly agreed-upon definition of intelligence in the literature is a difficult quest, but suggestions range from the strangest of notions regarding intelligence "as that which intelligence tests measure" to understanding intelligence as a neurological process, where differences in intelligence are understood in terms of the efficiency and capacity of the central nervous system (Eysenck, 1988; Kyllonen, 1996). More recent understandings focus more on intelligence function, namely to find and solve problems. Klein (1991), for example, defines general intelligence $(\mathrm{g})$ as "a general reasoning capacity useful in problem-solving tasks of all kinds" (p. 6), whereas Sternberg and co-writers (2000) in arguing for another kind of intelligence explain that "practical intelligence is what most people call common sense. It is the ability to adapt to, shape, and select everyday environments. Intelligence as conventionally defined may be useful in everyday life, but practical intelligence is indispensable" (p. xi). Howard Gardner (1983), however, is the only one to date to propose in theoretical terms why mankind's ability to listen to, appreciate, and make and play music should be considered an intelligence in its own right. Gardner's criteria for labeling a distinct set of cognitive functions an intelligence are (1) potential isolation by brain damage; (2) the existence of savants, prodigies, and other exceptional individuals; (3) an identifiable core operation or set of operations; (4) a distinctive developmental history together with a definable set of expert "end-state performances"; (5) an evolutionary history and plausibility; (6) support from experimental psychological tests; (7) support from psychometric testing, and (8) susceptibility to encoding in a symbol system.

One indication that music is a separate intelligence in a Gardnerian sense is the nature of the WilliamBeuren Syndrome (WBS), a neuro-developmental genetic disorder characterized by peaks and valleys in mental function. There are substantial impairments in cognitive domains such as reasoning, arithmetic ability, and spatial cognition. But interestingly musical skills are more or less intact (Levitin et al., 2004; Hopyan, Dennis, Weksberg, \& Cytrynbaum, 2001). Also magnetoencephalographic (MEG) and positron emission topographic investigations (so-called PETscans) of the brain indicate that the brain does indeed process music differently than, for example, language (Tervaniemi, 2001). Furthermore, the history of music is replete with anecdotal evidence as well as studied cases of both prodigies (Revesz, 1925; Bastian, 1989) and savants (Miller, 1989). 
The core operations of musical intelligence are those often included in psychometrically constructed musical aptitude tests: pitch, rhythm, tempo, timbre, loudness, and spatial location (Levitin, 2000; Justus \& Hutsler, 2005). However, included in this set of cognitive auditory functions should most likely also be added emotional responses to music (cf. Peretz, 2001; Hopyan et al., 2001). It is difficult to imagine any kind of musical activity without emotional responses being an integral part, although these are clearly less important to some and more so to others (Persson, 1993).

Musical intelligence is also beyond doubt subject to development; that is, the skills involved can be influenced by training and change from none to some by practicing them, and even further to an expertise level given extensive practice and suitable environments (Sosniak, 1985; Sloboda, 1991). However, more is likely to be required to actually be considered musically gifted. As discussed above, expertise scholars generally do not recognize genetic potential as significant in developing higher levels of achievement and accomplishment (Howe, Davidson, \& Sloboda, 1989; Sloboda \& Howe, 1999). A majority of the scientific community does however (e.g., Hassler, 1990; Thompson \& Plomin, 1993; Baltes, 1998; Gagné, 1999; Winner, 2000). It is the assumption for this conceptual model of musical giftedness also that development potential is determined by genetic factors. Thus, musical intelligence is separate from expertise behavior but not unrelated.

Also, Gardner's (1983) claim that musical intelligence has an evolutionary history is reasonably well substantiated in the literature. But this is also the intelligence criterion most open to speculation. Evidence for music as subject to evolution, and across species, is for the time being best regarded as suggestive and feasible rather than in any way absolute (Huron, 2001; Justus \& Hutsler, 2005). Primates, our closest evolutionary relatives, appear indeed to process music much like the human species does (Wright, Rivera, Hulse, Shyan, \& Neiworth, 2000), but they still do not make music. Gorillas simply do not sing opera! But it has been suggested that the song-like sounds of the gibbon monkey, bird song in general, and whale song are related to human song by function, namely sexual courtship (Miller, 1998). "Love me tender, love me sweet" serenaded Elvis Presley in his time. "I am wounded by love" lamented Guillaume de Machaut some 700 years before him. "My only idol is Love" is declared from stage in Hector Berlioz' opera Benvenuto Cellini. Is not love, in all its possible expressions, what singers through the centuries have mainly cherished in their art?

\section{The Key Skills of Musical Giftedness}

The key skills of musical giftedness are more difficult to outline because there is as yet no agreed definition of musical domain specificity, which they are and what constitutes them. However, while all musically gifted probably share the musical core skills, which additional skills they then need to excel in their chosen field of pursuit must by necessity differ to some degree. Researchers of musical giftedness could perhaps learn from Sport Sciences, where the physical attributes known to be significant for success in a certain sport also are of importance when screening for potentially gifted athletes (Adolph, 1978).

\section{The Case of Voice Artists}

Popular music icon Rod Stewart, for example, tours the world with great success (Ewbank \& Hildred, 2004). Thousands pilgrimage to his concerts and purchase his albums. But he would be unlikely to have made it as an opera singer, for the simple reason that his type of voice on stage would never be accepted by opera aficionados. Perhaps it also lacks the potential to even develop into a typical Western Classical opera voice. On the other hand, most opera singers could also not take Rod Stewart's place as an artist, because they do not have his unique voice and type of stage charisma. A voice is much more than merely the vocal chords. Its quality is dependent not only on their size and shape, on the technique learnt, practiced, and employed but also on the acoustical environment afforded by the body and its resonating spaces (cf. Sundberg, 1987). Hence, physical constitution plays a role too. In discussing voice and giftedness with famed American opera singer Dennis M. Heath (personal communication, 13 November, 2006), a former student of the legendary opera icon Birgit Nilsson among others, he defined "great singing" to me as follows: 
- Voice quality: resonant, clear, flexible, spontaneous, healthy, and with enough unforced volume to be heard.

- Range and registration: the need to know and use different registers

- Flexibility: an ability to effective fine motor control

- Language: students should learn the four basic language of the stage (German, French, Italian, and English)

- Musical style: knowledge of different historical periods and their musical practice.

- Musicianship: musical self-efficacy and general musical skills

- Health: taking care of one's voice as well as body and mind

- Stage presence: expression, communication, charisma

Both voice quality and flexibility are physiological characteristics. To identify giftedness in singing without taking these two into account, at least in Western Classical music, would not make sense.

However, there are also different demands on the opera singer as opposed to the popular singer. The opera singer needs to hone his or her acting skills for a successful career (Halper, 1999), whereas the superstars of popular music are currently more likely to be in need of considerable dancing skills-Madonna being the supreme example (St Michael, 2004). Both acting and dancing are non-musical skills in that they do probably not relate to the core skills. They are each domains of giftedness in their own right (Van Rossum, 2001; Noice \& Noice, 2002; compare also Simonton's chapter on cinematic talent this volume). In addition, the reasons for an individual to take on an acting career may be related to type of personality (Kavolis, 1963; Marchant-Haycox \& Wilson, 1992).

\section{Physical Attributes in Mastering a Musical Instrument}

That musical giftedness is multi-dimensional is an important point. It means that in order to specify what is domain specific in regard to musical giftedness there is a need to go beyond that which is auditory and also turn to social components and in addition also physiological components, depending of course on the function and purpose of the musical domain. To this end a few studies have investigated the physical attributes thought necessary to become a successful symphony orchestra musician, though with different outcomes. Lamp \& Keys (1932) tested how certain physical attributes could predict aptitude for specific instruments. They chose length and slenderness of fingers (violin), evenness of teeth (clarinet), and thickness of lip in relation to diameter of the mouth piece (Brass horn). Thickness of lips, they found, had some predictable value, whereas neither slenderness of fingers nor evenness of teeth seems related to success in their view. Musicians themselves, however, beg to differ-strongly! Mills (1985) surveyed three professional symphony orchestras to cull their observations and experiences of which physical attributes they considered essential in mastering a certain type of musical instrument (see Table 36.2).

Further research will have to establish whether making physical attributes a part of musical domain specificity is a fruitful way ahead, and if so also how. If so, one issue that then needs to be considered is the compensation phenomenon, where someone void of appropriate attributes actually succeeds exceedingly well in spite of this fact (e.g., Feldman, 1986).

Next to be considered for musical domain specificity are motor skills, especially the finer motor skills needed for mastering musical instruments. Motor skills are, needless to say, also subject to heredity. Some will be able to learn them more efficiently and quicker than others. Fox, Herschberger, \& Bouchard, (1996) write of motor skills that practice with feedback is funda-

Table 36.2 Physical attributes considered significant for mastering musical instruments (adapted from Mills, 1987)

\begin{tabular}{ll}
\hline $\begin{array}{l}\text { Types of } \\
\text { instruments }\end{array}$ & Proposed physical significant attributes \\
\hline Bowed strings & $\begin{array}{l}\text { Overall physical coordination } \\
\text { Broad left-hand fingertips } \\
\text { Large hands (for cello and bass especially) } \\
\text { Overall physical coordination } \\
\text { Wind }\end{array}$ \\
& $\begin{array}{l}\text { No double-jointedness } \\
\text { Large hand span }\end{array}$ \\
& Thin lips (flute, trumpet, horn) \\
& Thick lips (trombone and tuba) \\
& Tall \\
Harp and & Large hand span (harp) \\
percussion & Fleshy finger tips (harp) \\
& No double-jointedness (harp)
\end{tabular}


mental in acquiring motor skills. However, heredity cannot be overlooked because with practice "everyone improves, but some improve more than others" (p. 356). A musically fairly capable individual therefore, may well have all the cognitive attributes as well as emotive skills of musical giftedness but might simultaneously be wanting in efficient motor learning, which in reality would mean having great musical ideas but not sufficient technical skill to manifest them. It could also be the other way round, which is more often talked about among musicians: someone has a brilliant, almost unbelievable, facility for technique, but appears simultaneously to be lacking in musical ideas to communicate. Pianist Paul Badura-Skoda (in Dubal, 1985), for example, observes that "today so many pianists play like robots ... I can admire their technique but they leave their audiences cold" (p. 52). Another pianist of renown, Jorge Bolet, believes mechanical aptitude is an inborn talent: "What I do at the keyboard has always been done with a certain amount of ease" (in Dubal, 1986, p. 78). Presumably, the musically gifted musician has both the cognitive attributes and a considerable facility for motor learning. But what exactly is the nature this "considerable facility"? A fair assumption would be that it corresponds to different levels of information processing constraints at a neuronal level as demonstrated by Eysenck (1988) in reference to the possible cause for differences in intelligence level (see also Stelmach, 1982; Illert, 1993). It has been suggested that the maximum normal speed at which, for example, fingers can be made to move per second in scale playing is about $15-20$ times. Note that the virtuoso repertoire often exceeds these constraints suggesting that some are indeed more able to execute certain motor patterns than others (Sloboda, 2000; Collins, 2002).

Expressive skills are also an inevitable candidate for considering domain-specific musical gifted behavior. A good amount of research has been done in order to understand what musical expression actually is in terms of motor behavior (Shafer, 1976; Clarke, 1988; Palmer \& Meyer, 2000). In fact, research has arrived at enough an understanding of motor programming in this respect that it is now possible to program computer algorithms and recreate by Artificial Intelligence means an artistically appealing and synthesized performance (Sundberg, 1988; Friberg, 1991). However, cognitive scientists have remained true to study observed behavior only. While we know a great deal of overt musical behavior, few have devoted themselves to the conceptual learning of music, which in all likelihood dictates how a piece of music is actually performed. Musicians from all eras, writes Persson (2001), "and no doubt in all genres of music, are indeed 'sensors of emotions and sensitivity', and subjectivity is, in a variety of ways, most probably the basis of the musical pursuit. It is helpful then, both for future research and in understanding the phenomenology of musical endeavors, to term the dynamic nature of this emotional basis from which musicians appear to draw motivation, construe artistic understanding, and generate performances, a musical reality akin to the Kellyan (1963) notion of personal constructs" (p. 284). How musical reality affects the nature of a performance in terms of tempo, dynamics, articulation, and so on is easily demonstrated by asking a musician to depict a certain event or scenario in the way that he or she plays (Persson, 1993). Manipulating the musical structure affects in various ways how the musician and his or her audience perceive the performance in terms of emotional response (Juslin, 2001). For example, it would be difficult to experience or communicate a feeling of sadness if tempo is very rapid. How then does a musical reality relate to giftedness? Given that emotionality, although construed in different ways by musicians, is an inevitable and intrinsic part of making and performing music, it could be argued that there are traits of personality involved in musical giftedness. Kemp (1996) in surveying the research on musical ability and personality found that musicians tend to score highly on Cattell (1973) pathemia, and sensitivity as well as on Eysenck's (1967) introversion, the significance of which involves, Kemp suggests (1996), "the kinaesthetic sensation in musical performance, offering support to the notion that visceral brain activity is of fundamental importance" (p. 84). It is reasonable to argue therefore that as a further additional aspect of domain specificity would be emotive skills: a propensity for emotional self-indulgence in a variety of ways, or hedonism, in that particularly musicians and singers would strive to optimize their emotional experiences when playing and that this strive, or perhaps need, would also be stronger in a gifted individual than in an able but not necessarily gifted musician. A relationship between music ability and altered states of consciousness has for example been amply demonstrated (Biasutti, 1990; Tart, 1990). 
The last potential aspect of musical giftedness domain specificity discussed here is inner hearing, which Campbell (1989) explains is "... [when] one using notation 'hears what he sees. And sees what he hears' once the skill has been developed (p. 304). Brodsky \& Henik (1997) were able to demonstrate by a series of experiments first that musical inner hearing really does exist as a distinct form of cognition (see also Crowder \& Pitt, 1992; Halpern, 1992: Gordon, 1995) and second that not all musicians in their research sample had this ability although they were all highly trained musicians. Similar results were obtained by Hallam (1995). She found that only two out of three musicians were able to hear music from the printed page of a score. While these researchers studied performers and surmised that inner hearing in one way or another is part of highly skilled musicians array of abilities, I would suggest differentiating that assumption by arguing that while inner hearing is no doubt a facilitating asset to performers who has the ability, it is crucial to a composer or a conductor. I propose that inner hearing particularly is a skill characteristic of a musically gifted composer or conductor. Danish composer Vagn Holmboe (1991) describes the genesis of his Symphony no. 6: “... without my knowing one note of the music. It stood quite clear to me as a larger totality in my consciousness; I knew how it had to be ... sounds streamed forth now as if on their own; they sang in me, and I had to use all the abil- ity and technique I had" (p. 39). Furthermore, Hans von Bülow, the first of the Maestro Conductors divided conductors somewhat facetiously into two groups: those with their head in the score and those with the scores in their head (see Bamberger, 1965). Conductors need to be able to hear the score from the score alone.

In conclusion, musical giftedness is a multidimensional construct. In order to make sense of the multitude of research into musical behavior and facilitate future research and a better understanding of giftedness in music, as opposed to music as a general capacity common to all, it needs to be studied as a domain-specific phenomenon.

There are clearly certain aspects of musical behavior that are more important in one pursuit than in another. Few of them have previously been brought together in a model outlining musical giftedness (cf. Chan, 2005). I therefore tentatively suggest the following division of domain-specific skills (see Table 36.3). This proposal cannot be understood as conclusive or exhaustive in any way. It is mainly an effort to piece together many years of research in several fields of study as well as to bring together scattered ideas and anecdotal assumptions of the musicians themselves. Also, the piecing together of the model unavoidably rests on my own subjective evaluation of available information: empirical and other. At the very least the outline can serve well as a heuristic for future research.
Table 36.3 A suggestion how musical giftedness could be outlined in terms of giftedness domains and their domain specific skills. Note that this division pertains to Western classical music

\begin{tabular}{lll}
\hline Giftedness domain & Domain specific key skills & Type \\
\hline Voice performance & Voice quality & Physiological \\
& Voice motor function & Physiological \\
& Acting skills & Personality \\
& Auditory skills & Cognitive \\
& Musical memory & Cognitive \\
& Emotive skills & Personality \\
& & \\
Instrument performance & Motor function & Physiological \\
& Appropriate physical attributes & Physiological \\
& Auditory skills & Cognitive \\
& Musical memory & Cognitive \\
& Emotive skills & Personality \\
& Auditory skills & \\
Composing/Conducting/Arranging & Cognitive \\
& Emoativity & Cognitive \\
& & Personality \\
& Personality \\
\hline
\end{tabular}




\section{Musical Giftedness and Heredity}

As the musical upbringing of gifted Western Classical musicians has been systematically charted and is now well known and the significance of extensive practice, mentors, and supportive and stimulating environments well documented (Sosniak, 1985; Bastian, 1989; Manturzewska, 1990; Sloboda, 1991; Ericsson et al., 1993; Sloboda \& Howe, 1991; Howe \& Sloboda, 1991a,b), it seems that the question of nature versus nurture has rekindled with considerable intensity. However, while encouragement, opportunity, and extensive practicing certainly would mean a great deal to any musician, gifted or not, it is difficult to overlook individual limits to what can be achieved (Hunt, 1997). Arguments against genetic impact on various aspects of development come into a different light when compared with how sport scientists currently understand future talent identification in sports. McArdle, Katch, $\&$ Katch, (2001) envision the following regarding future gifted athletes:

\begin{abstract}
The next decades ... research will build upon the rapidly developing knowledge base about gene expression and the human gene map for performance and health related phenotypes. In the not-too-distant future, sport scientists will routinely incorporate simplified molecular techniques to assess and individual's potential for strength, endurance, and other traits important to exercise performance ... Coaches and trainers in the future decades will undoubtedly apply technologies from molecular medicine to genetically screen young children for gene clusters that indicate potential for desirable athletic traits (p. 994).
\end{abstract}

Thus, sport scientists have a different basis and a somewhat different-and I think a more candid and correct-debate. There is no denial of the impact of genetic predisposition, but there exists a debate what to do with the knowledge we do have. Not everyone thinks screening on the basis of genetic predisposition is desirable, and it does raise a number of ethical questions (Murray, 1991; Mallia \& ten Have, 2005; Miah \& Rich, 2006). However, the current state of molecular medicine nevertheless makes it possible to envision genetic identification of talent given that the physiological and cognitive prerequisites for any given domain of pursuit are known. Surely music in this respect could not be much different than sports? To a degree musically gifted individuals such as performers and singers could well be looked upon as athletes.
Unfortunately hidden more or less political agendas sometimes interfere in deciding what is "true" and what is not, quite irrespective of what evidence actually suggest (Segerstråle, 2000). Never is controversy more rampant than when heredity is discussed. It would be more honest and definitely more correct, like in sports, to debate with regard to musical giftedness what kind of a future we wish to have rather than trying to construct a future based on ignoring certain facts

\section{The Nature of Stimulation and Development Differs Between Domains}

Kleinen (2002) argues that studying popular musicians will probably extend the scientific understanding of musical giftedness. He even goes so far as to say that the research effort to date has been "blocked by the cult of genius and other unreflected myths" (p. 8). Rosenbrock (2003) makes much the same observation and claim. It is worth noting again the parallel to the quest for understanding human intelligence. "In seeking to understand intelligence," Sternberg (1988) suggests, "we should inhibit our desire to look in obscure nooks and crannies, and dampen our fascination with the unusual and the bizarre. Instead, we should look in the most obvious of places-ordinary people living their everyday lives - to gain some insight into what intelligence is, how it should be measured and how it might be improved" (p. 6).

Kleinen (1997) studied Jazz and Rock musicians and did indeed find differences between Western classically trained musicians, always strictly and formally trained, and popular musicians, who have more or less learnt their musical skills much on their own (Table 36.4).

Campbell-Robinson, Buck, \& Cuthbert (1991), on the other hand, studied a number of local and traditional musicians in various countries. They also found that formal training in music was usually missing and that the early beginnings of their musical development tended to be a very lonely one:

The portrait we have painted of the local musicians we have interviewed is one of lonely, talented children who turn to music with an incredible dedication at an early age. Often their formal musical education, if any, is minimal, and they begin to train themselves, relying frequently on the help of other musicians, some of whom are family members. As adults our musicians see themselves as less 
Table 36.4 Some differences between the musical development of Western Classical musicians and Jazz and Rock musicians (adapted from Kleinen, 1997)

\begin{tabular}{lll}
\hline Variables of study & Western Classical & Jazz and Rock \\
\hline Technique & Has highest priority & Feeling is more important \\
Social facilitators & Parents and teachers & Group members, friends \\
Social situation & Loneliness & Member of a group \\
Performance priorities & By notation and exactitude & By ear, by feeling \\
Nature of learning & Formal teaching by others & Learning on your own \\
\hline
\end{tabular}

bound by the traditional mores and values of the social surroundings, being both more tolerant and socially sophisticated than friends from the past who have pursued more mainstream occupations (p. 223).

Thus, a widened study of musical giftedness, differentiating research samples by encompassing different genres of music as well as cultures, could substantiate and extend the findings that, for example, well-known precursors of developing musical giftedness in a Western Classical music context (Howe \& Sloboda, 1991a,b; Manturzewska, 1990; Sloboda \& Howe, 1991) are different for talented musicians of other genres, sub-cultures, and cultures.

\section{Everyone Has Musical Capacity}

Shuter-Dyson (1982) concludes that "the ability to make and apprehend music is inherent in all humans, but in another sense aptitude varies among individuals and may set a limit on ultimate achievement, no matter how favorable the environmental influences nor how highly motivated the person" (p. 393). It is very difficult to overlook the notion of a human general capacity for music. All known cultures, present and past, have or have had music — as opposed to nonmusic (see Merriam, 1964) - as an integral part of that culture (Blacking, 1995; Cross, 2001). It is difficult to argue, for example, that an individual is not musical, since most people at least to some extent have all the perceptual and cognitive attributes considered particularly related to music. The few who are de facto "unmusical" are likely to be neurologically dysfunctional—congenitally or traumatically-in relation to this general music capacity (Kalmus \& Fry, 1980; Ayotte, Peretz, Rousseau, Bard, \& Bojanowski, 2000; Peretz et al., 2002; Stewart \& Walsh, 2002). Humans are a musical species, and lack of individual skill is not to be equaled to being void of musical capacity (Blacking, 1987; Sloboda, Davidson, \& Howe, 1994; Koelsch, Tomas, \& Friederici, 2000).
Shuter-Dyson (1981) further points out that if Seashore's $(1919,1938)$ idea of separate musical functions was accurate, intercorrelations between the tests included in the battery he devised to assess musical aptitude would as a rule be low and the search for underlying factors would yield specific ones. This has proven not to be the case. However, while these results may be true in a psychometrical sense, a test is also subject to construct validity. Is the way that Seashore operationalized his notions on independent abilities actually reflected in the test battery? What does it really measure? While high intercorrelations between the tested musical functions perhaps deflate the intentions of Seashore's (1919) test battery assessing aural skills such as pitch, consonance, tonal memory, time and rhythm, it does not necessarily make the idea of multiple musical functions null and void. There may well be other skills at play, which were not considered by Seashore and others at the time; skills which are not necessarily tied to auditory perception as already demonstrated in this chapter on musical giftedness.

It follows of course that lack of individual and developed musical skill is not to be equaled to being void of musical capacity. Irrespective of whether general or specific musical behavior playing an instrument or singing first needs learning and practicing-supervised or by one's own accord. Practicing therefore has attracted many researchers particular interest.

\section{Practice Makes Perfect}

It is not possible to even consider becoming an expert in any field without first having accumulated a considerable amount of time practicing the skills required to reach an expert level (cf. Ericsson, 1996). Several studies over the years have scrutinized musicians and their practicing. Comparisons were made, for example, between conservatory student violinists likely to become internationally recognized in due time, 
good student violinists, and music teachers (Ericsson et al., 1993). By 18 years of age the difference in self-reported accumulated practice is considerable: the most promising students had invested 7,410 hours of practicing, while good students reached 5,301 hours and music teachers 3,420 hours. Note that practicing in the development toward expert levels is deliberate (Ericsson, Tesch-Römer, \& Krampe, 1990). This means planned, strategic, and to some extent enforced practicing in that extrinsic motivation is stronger than intrinsic motivation. Practicing is not necessarily enjoyable, but there are events such as contests or concerts ahead for which practicing is necessary. So, musicians practice anyway. Less successful musicians, like amateurs, turn their practicing into something more enjoyable and interact with others more than practice systematically; an indulgence which, according to Ericsson et al. (1993), leads to little improvement in skill. As Harnischmacher (1997) puts it: "...practice times-without the extrinsic "push" of performance preparation - tend to be influenced by planning and action-oriented aspects of personality" (p. 84). Also, practicing must be kept up over time to maintain the skill (Krampe \& Ericsson, 1996).

Beyond any doubt, behind every gifted musician is a considerable investment in systematic training of the skills required for their chosen pursuit. Expertise, or in Subotnik's (2000) terminology: elite level talent, does not come cheap!

\section{Identifying Musical Giftedness}

In surveying the literature on the many aspects of musical behavior one issue stands out clearly regarding the identification of musical giftedness: early attempts by pioneering researchers to detect musical aptitude by psychometric testing are far from sufficient. The reason is that musical giftedness is not a matter of auditory cognition and perception only. However, in recent years, with further research and also because researchers have turned to other sources of data than what perceptual testing can provide; they have turned to musicians themselves to ask qualitative questions. The understanding of musical giftedness has as a result extended considerably. As has been discussed earlier, however, these efforts are still in their infancy since there is an urgent need to recognize that the notion of musical giftedness by and large is biased toward Western Classical music and that social consensus assessment of talent, at least for research purposes, is too ambiguous to be of much value.

Musical giftedness therefore needs to be identified, and understood, along three dimensions: (1) as something objective and generalizable, (2) as something subjective and individual, and (3) as something social as based on estimated value or appreciation within a context of supply and demand. Implied here is also that there are both commonalities and unique features to each domain of musical pursuit.

Shuter-Dyson (1981) has provided an excellent evaluation of the earlier attempts to identify musical giftedness, so better here to focus on more recent attempts to outline musical giftedness and what separates the gifted from the non-gifted. These attempts have, more or less, all been impressed by expertise research and fully acknowledge the tantamount significance of practice and social precursors in order to develop excellence to its fullest in a musical domain. They have in addition also kept the significance of auditory skills. But apart from components such as these the understanding of musical giftedness has become more elaborate (Table 36.5 ).

Table 36.5 Identifying markers for musical giftedness as suggested in the recent literature. Note that markers suggested by Winner \& Martino (2000) and Haroutounian (2000, 2002) are culled from empirical studies, whereas Bastian (1989) and Subotnik et al., (2004) report musicians' own understanding of what musical giftedness is and/or what it takes to be recognized as such

Winner \& Martino (2000): $\quad$ Haroutounian (2000, 2002):

Early interest in musical sounds Perceptual awareness

Musical memory

Perfect pitch

Musical generativity

Multiple music-cognitive representation

Sensitivity to emotion in music

Bastian (1989):

Expressive abilities

Emotionality

Learning with ease

Musical memory

Physical suitability

Auditory skills

Multi-skilled across domains
Perceptual discrimination Metaperception Creative interpretation

Behavior/

Performance Motivation

Subotnik et al. (2004):

Persistence

Self-confidence

Knowledge of Self

Socially skilled

Self-promotive

Learning with ease

Risk-taking

Intrinsic motivation

Charisma 
Winner \& Martino (2000), as part of cognition, suggest musical memory and perfect pitch as identifying markers. They also state that musically gifted individuals cognitively represent music in more ways than non-gifted individuals (cf. Bamberger, 1991). In addition, they point out that an early interest in musical sounds and perfect pitch are typical. The early interest in musical sounds, or perhaps rather an oversensitivity to sound, has been suggested by Noy (1968) and Nass (1975) also. Perfect (or absolute) pitch, however, may not necessarily be associated with giftedness. It is not an uncommon phenomenon. In one study $15 \%$ of the participants had perfect pitch (Baharloo, Johnston, Service, Gitschier, \& Freimer, 1998) and in another 32\% (Gregersen, Kowalsky, Kohn, \& WestMartin, 1999). It can be learnt by some and has been demonstrated in both gifted individuals and individuals with developmental disorders alike (Dixon-Ward \& Burns, 1982). When studying piano performance in Sweden and Canada in the 1980s, I quickly learned that more than anything the possession of perfect pitch awarded social status. Students who did not have the ability were usually in awe of those who did. Musically gifted individuals are generative. By this Winner and Martino mean that they are able to transpose, improvise, and compose. It is worth noting that composer and musician was often one and the same prior to the twentieth century, and it was more rule than exception that they improvised also. It is only quite recently in history that musicians have become more or less specialized and, particularly, performance and composing are regarded as unique professions. In popular music, especially at the outset of an artist's career, this tradition largely remains. Popular musicians tend to perform their own music. New to the signifiers of musical giftedness Winner and Martino introduce sensitivity to emotion in music. This is an important addition and one that has been conspicuously absent from early scientific attempts of trying to understand musical giftedness.

Haroutounian $(2000,2002)$ produces a similar set of signifying aspects of musical giftedness, but she encompasses the cognitive skills by using several and, in all likelihood, somewhat overlapping terms such as perceptual awareness and discrimination, behavior and performance, and metaperception. Perceptual awareness and discrimination are considered "biological givens." They are equal to musical intelligence and involve, in Haroutounian's understanding, above all a propensity for awareness of sound and listening carefully. Motivation is perhaps an obvious issue to consider, although motivation for pursuing a musical career differs from one musician to another: (1) a hedonic motive-the search for positive emotional experiences, (2) a social motive-the importance of group identity and belonging, and (3) achievement motives (Persson et al., 1992). In reference to creative interpretation as one important signifier Haroutounian (2000) writes: "The most decisive factor of determining potential musical talent in children, according to respondents in every interview, rested on criteria that were related to the child's creative and expressive involvement in musical activities" (p. 146). The core skills of musical giftedness: auditory skills and musical memory are subsumed under behavior and performance. One important criterion in Haroutounian's checklist is metaperception, which is defined as the perceptual and cognitive process in which the musician: (a) senses the sound internally, (b) remembers this sound, (c) manipulates the sound to match expressive intentions, and (d) communicates this creative interpretations of sound to others.

Bastian (1989) presents an entirely different, but complimenting, list of criteria culled from questionnaires answered by highly gifted young German musicians. Needless to say, cognitive skills like musical memory, learning with ease, and auditory skills are central. But from musicians' perspective expressive abilities are considered the most important skills by far closely followed by emotionality; a musician's ability and will to experience music affectively. These musicians also, like the one's interviewed by Mills (1985), argue for the importance of certain physical attributes to facilitate mastering a musical instrument. One very interesting finding by Bastian in this major research project is the fact that a surprising number of the participants were polymaths; they were multitalented (see Root-Bernstein, this volume). Some played several instruments to a very high level, whereas others in addition to their instrument wrote poems also or devoted themselves to visual arts-all pursued to a high level of skill. One example is the following poem of a 17-yearold bassoonist. The poem here is rendered in translation from German by the current author (appearing anonymously in Bastian, 1999; p. 290) 


\section{The homeless}

Barely in sight he lies, chameleon of the city, between withered grass and leaves sees growing above him the sky

In green markings "founded by city..." to him belongs

no bench in the park,

only

the sky

in between

Already the bottle

is hidden

with which

he would be able to change

colors

The last, and currently the most recent study, discussed in this context is a study by Subotnik and her fellow researchers (2004; see also Subotnik this volume) on "secrets of success in music performance". Questions posed to participants do not directly address the question of giftedness but rather what it currently takes to succeed as a professional gifted musician. This is an inventive way of enquiring about giftedness. It prompts respondents to account for aspects of being musically gifted rarely addressed in research. As valuable and welcome this is, it raises further questions also. Only one cognitive prerequisite is mentioned by the participants: the importance of learning with ease. All the other characteristics regarded as necessary relate, one way or another, to personality, namely persistence, self-confidence, risk-taking, intrinsic motivation, and charisma. However, the successful gifted individual, according to participants, must also be self-promoting, socially skilled, and have a considerable knowledge of Self-three characteristics, which in part could be subsumed as ambition. In this perspective, the successful gifted musician is well aware of market forces and the principle of supply and demand. The long-lasting image of the musician of the Romantic Era as the inspired, exalted and divinely touched prophet, has transformed into a more or less stout entrepreneurial business person aiming to negotiate his or her own contracts with the best concert agents around the world, taking every opportunity to finding something that will further their career (see Shavinina's chapter on entrepreneurial giftedness in this volume). Given that this really outlines successful musicians; that is, describes what respondents felt what successful gifted musicians actually are like rather than how they in their experience would need to be like, the suggested characteristics provide a most interesting comparison to Kemp's (1996) overview of research on musicians and their typical type of personality:

\begin{abstract}
Evidence ... support the notion that introversion appears to be positively linked to levels of musical performance. In musicians, the trait appears to manifest itself particularly in a tendency to direct energy inwards, resulting in a reserved and introspective temperament. At the same time, however, it suggests considerable resourcefulness, self-sufficiency, and personal inner strength. The musician can be perceived as a "bold introvert" who possesses the capacity to be comfortable in solitude during long periods of practice but at the same time is able to mobilize sufficient degrees of autonomy in performance. This form of introversion appears to take on aspects of the "schizoid" personality, individuals developing their sense of control over aesthetic objects and generating a sense of their own omnipotence (pp. 49-50).
\end{abstract}

In addition, Rovics (1984) has found that musicians often suffer from a serious lack of self-esteem, while Storr (1972) regards the creative mind as schizoid. As such the creative individual is introverted and somewhat reclusive, using his or her creativity instrumentally to remain aloof from social contexts but yet uphold a sense of mastery, if not a sense of omnipotence.

It seems that the research on musicians' personality to some extent speaks against the respondents interviewed by Subotnik and her colleagues (2004) suggesting a discrepancy between who musicians often are and the persons they perhaps need to be in a rationalist and market-oriented context (Ritzer, 1992). Celebrated violinist Nigel Kennedy (1991) came to study at the Juilliard School of Music in New York, after having been brought up musically by Yehudi Menuhin. He disliked the famous music school intensely and made the following observation: "Don't misunderstand me, the Juilliard School was full of brilliant players all hungry to succeed, but it was their progress which preoccupied them and not the discovery of the music and its emotions" (p. 18). The multitude of research done in Performance Art Medicine focusing on musicians' health hazards, physical and psychological, suggests that mu- 
sicians generally do not fare well in controlled rationalist environments. They are prone to develop a variety of stress-related problems and anxieties (Ostwald \& Avery, 1991; Nagel, 1993; Persson, 1995; Phyland, Oates, \& Greenwood, 1999; Amadio \& Tubiana, 2000). Another line of research has looked at the relationship between what Redfield-Jamison (1993) terms "the artistic temperament" and above all manic-depressive illness. She poses a question worth considering, namely "if manic-depressive illness and its associated temperaments are relatively common in artists, writers, and composers, and if the illness, at least to some extent, an important part of what makes the work what it is, what are the implications of treating the underlying disease and its temperaments?" (p. 241). In other words, if no emotional problems (or emotionality in more general terms), then maybe also no astounding creative production. Rothenberg (1990) makes similar reflections.

Irrespective of whether gifted musicians are at times psychologically disordered or not, psychiatric studies and observations of artists nevertheless reinforces the notion of the artist as an emotionally oriented individual further. That is to say, the introverted ones who have developed a considerable affective relationship to their music making are likely to be as far from "stout entrepreneurial business persons" as can possibly be, which in turn raises the question who are the persistent, self-promoting, charismatic, and intrinsically motivated risk-taking entrepreneurs that Subotnik and colleagues seek (see also Subotnik, 2003)? If, in Kennedy's (1991) words, The Juilliard School of Music and other similar institutions "[have] the stench of raw ambition, of ruthless professional people only too happy to conform to whatever is musically suitable to succeed" (p. 18), then maybe these famous institutions of musical learning are not necessarily the most opportune places in which to find musical giftedness based emotive and creative skills?

Beyond any doubt, however, musical giftedness can be identified by its core skills. For this there is consensus. Musical giftedness needs also be identified by its key skills, but research is scarce and so far only in its infancy. Finally, identification must be understood as contextual. The attribution of giftedness is more that just inherent ability or capacity. Social acceptance and tolerance are also issues to consider
(Persson, 2006) and to my knowledge such research has not yet even begun.

\section{Concluding Remarks}

By involving musicians, their teachers, parents, and mentors in the research process by interview and observation, thereby extending empirical knowledge beyond psychometric notions of ability, much has been gained. It is certainly of interest to know, at an individual level, how music is experienced; how motivational triggers, development, instruction, the nature of practicing, and so on, are understood and construed. However, there are pitfalls in this line of research, be it either quantitatively or qualitatively oriented. We cannot assume that respondents are always correct and that they always know themselves well enough to be able to establish for example causality. That which is true in a phenomenological sense may not correspond to how things actually are in a more objective sense. Sloboda, Davidson, \& Howe (1994) term this problem "folk psychology". One good example of the problem in question is asking different relevant groups what they believe makes an individual musically gifted. This is what researchers Evans, Bickel, \& Pendarvis, (2000) did. They found that students attribute much of their success to innate talent and hard work, whereas they also feel that family and friends have, in fact, discouraged their musical development. Their parents, on the other hand, report their children to be of only moderate innate ability and rather emphasize the significance of support and encouragement given by themselves and their friends. Who is correct? We cannot know without redesigning the study and follow a different research strategy.

Another possible pitfall in research, especially when involving young children in a study, is to use "grownup" conceptions of what goes on in a child's mind. What we interpret as "delight in musical sounds," for example, may be nothing of the sort. It could simply be a child's — any child's - natural heightened attentiveness to novelty (Sloboda, 1985). I think similarly we must be wary of attributing aspects such intentional creativity, musical expression, and musical involvement also. There is certainly a danger that we see 
what we wish to see and thus risking to invalidate the research.

A third problem in researching musical giftedness is of course, in view of what has been discussed in this chapter, whether the ones subject to study in various research projects are truly and objectively gifted? Considering the bias towards Western classical music in research, the social forces of supply and demand, and the ambiguity of social consensus procedures, it would be somewhat presumptuous to argue that everyone studied as musically gifted actually is. At the very least many, perhaps most, have certainly been gifted-but perhaps in different ways due to lack of a general definition of musical giftedness!

\section{References}

Adler, M. (1985, March). Stardom and talent. American Economic Review, 75(1), 208-212.

Adolph, H. (1978). Talentsuche und Talentförderung im Sport als Kooperationsfeld von Schule und Verein [The search for talent and talent training in sport as a field of cooperation between school and parents] PhD Dissertation in psychology/Sport Science no. 0E05 (Gesamthochschule Kassel, Germany).

Albert, R. S. (1992). Genius and eminence (2nd ed.). Oxford, UK: Pergamon Press.

Amadio, p. C., \& Tubiana, R. (2000). Medical problems of the instrumentalist musician. London: Martin Dunitz.

Andreas, R. (1993). Improvisation. In H. Bruhn, R. Oerter, \& H. Rösing (Eds.), Musicpsychologie. Ein Handbuch (pp. 506513). Hamburg, Germany: Rohwolts Encyclopädie.

Ayotte, J., Peretz, I., Rousseau, I., Bard, C., \& Bojanowski, M., (2000). Patterns of music agnosia associated with middle cerebral artery infarcts. Brain, 123, 1926-1938.

Baharloo, S., Johnston, p. A., Service, S. K., Gitschier, J., \& Freimer, N. B. (1998). Absolute pitch: an approach for identification of genetic and non-genetic components. American Journal of Human Genials, 62, 224-231.

Baltes, p. B. (1998). Testing the limits of ontogenetic sources of talent and excellence. Behavioral and Brain Sciences, 21, 407-408.

Bamberger, C. (Ed.). (1965). The conductor's art. New York: Columbia University Press.

Bamberger, J. (1991). The mind behind the musical ear. How children develop musical intelligence. Cambridge, MA: Harvard University Press.

Bandura, A. (1990). Conclusion: Reflections on nonability determinants of competence. In R. J. Sternberg \& J. Kolligian, Jr. (Eds.), Competence considered (pp. 315-362). London: Yale University Press.

Barret, M. (2006). Creative collaboration: an eminence study of teaching and learning in music. Psychology of Music, 34(2), 192-218.
Bastian, H. G. (1987). Jugend musiziert. Der Wettbewerb in der Sicht von Teilnehmern und Verantwortlichen [Young musicians perform. Competitions from the perspective of participants and contest organizers]. Mainz, Germany: Schott.

Bastian, H. G. (1989). Leben für Musik. Eine Biographie-Studie über musikalische (Hoch-) Begabungen [To live for music. A biographical study of musical high ability]. Mainz: Schott.

Biasutti, M. (1990). Music ability and altered states of consciousness: an experimental study. International Journal of Psychosomatics, 37(1-4), 82-85.

Blacking, J. (1987). A common-sense view of all music. Cambridge, UK: Cambridge University Press.

Blacking, J. (1995). Music, culture and experience. Chicago, IL: University of Chicago Press.

Boyd, J., \& George-Warren, H. (1992). Musicians in tune. Seventy-five contemporary musicians discuss the creative process. New York: Fireside Books.

Braudy, L. (1997). The frenzy of renown. Fame and its history. New York: Vintage Books.

Brenneis, D. (1990). Musical imaginations: comparative perspectives on musical creativity. In M. A. Runco \& R. S. Albert (Eds.), Theories of creativity (pp. 170-189). Newbury Park, CA: Sage.

Brodsky, W., \& Henik, A. (1997). Demonstrating inner hearing among musicians. Paper presented at the Third Triennial Conference of the European Society for the Cognitive Sciences of Music (ESCOM), Uppsala, Sweden, 7-12 1997.

Bruer, J. T. (2002). The myth of the first three years. A new understanding of early brain development and lifelong learning. New York: Free Press.

Bunt, L. (1994). Music therapy. An art beyond words. London: Routledge.

Campbell, p. S. (1989). Dalcroze reconstructed: an application of music learning theory to the principles of Jacques Dalcroze. In D. L. Walters \& C. C. Taggart (Eds.), Readings in Music Learning Theory (pp. 301-315). Chicago, Ill: GIA Publishers, Inc.

Campbell, D. (2001). The Mozart Effect: Tapping the power of music to heal the Body, strengthen the mind, and unlock the creative spirit. London: Quill.

Campbell-Robinson, D., Buck, E. B., \& Cuthbert, M. (1991). Music at the margins. Popular music and global cultural diversity. London: Sage.

Cattell, R. B. (1973). Personality and mood by questionnaire: a handbook of interpretive theory, psychometrics, and practical procedures. San Fransisco, CA: Jossey-Bass.

Chabris, C. F. (1999). Prelude or requiem for the "Mozart effect"?. Nature, 400, 826-827.

Chan, A. (2005). The solo pianist. A critical analysis of concepts of giftedness (Thesis in partial fulfillment of the Master of Arts Degree), Concordia University, Montreal, Canada.

Clarke, E. F. (1988). Generative principles in music performance. In J. A. Sloboda (Ed.), Generative processes in music. The psychology of performance, improvisation, and composition (pp. 1-26). Oxford, UK: Oxford University Press.

Collins, N. (2002). Relating transhuman virtuosity to human performance. Proceedings of MAXIS, Sheffield Hallam University, Sheffield, UK, April 12-14. 
Coon, H., \& Carey, G. (1989). Genetic and environmental determinants of musical ability in twins. Behavior Genetics, 19(2), $183-193$.

Cross, I. (2001). Music, mind and evolution. Psychology of music, 29(1), 95-102.

Crowder, R. G., \& Pitt, M. A. (1992). Research on memory/imagery for musical timbre. In D. Reisberg (Ed.), Auditory imagery (pp. 29-44). Hillsdale, NJ: Lawrence Erlbaum.

Dennis, I., \& Tapfield, p. (Eds.). (1996). Human abilities. Their nature and measurement. Mahwah, NJ: Erlbaum.

De la Motte-Haber, H. (1985). Handbuch der Musikpsychologie [A handbook of music psychology]. Laaber, Germany: Laaber-Verlag.

Deliège, I., \& Sloboda, J. A. (Eds.). (1996). Musical beginnings. Origins and development of musical competence. Oxford, UK: Oxford University Press.

Dixon-Ward, W., \& Burns, E. M. (1982). Absolute pitch., In D. Deutsch (Ed.), The psychology of music (pp. 431-451). San Diego, CA: Academic Press, Inc.

Dubal, D. (1985). The world of the concert pianist. Conversations with 35 internationally celebrated pianists. London: Victor Gollancz.

Eisner, E. W. (1998). Does experience in the arts boost academic achievement? Journal of Art \& Design Education, 17(1), 51-60.

Elliot, D. (1987). Assessing musical performance. British Journal of Music Education, 4(2), 157-188.

Ericsson, K. A. (Ed.). (1996). The road to excellence. The acquisition of expert performance in the arts and sciences, sports and games. Mahwah, NJ: Lawrence Erlbaum.

Ericsson, K. A., Krampe, R. T., \& Tesch-Römer, C. (1993). The role of deliberate practice in the acquisition of expert performance. Psychological Review, 100(3), 363-406.

Ericsson, K. A., Tesch-Römer, C., \& Krampe, R. T. (1990). The role of practice and motivation in the acquisition of expert-level performance in real life. In M. J. A. Howe (Ed.), Encouraging the development of exceptional skills and talents (pp. 109-130). Leicester, UK: The British Psychological Society.

Evans, R. J., Bickel, R., \& Pendarvis, E. D. (2000). Musical: innate or acquired? Perceptions of students, parents, and teachers. Gifted Child Quarterly, 44(2), 80-90.

Ewbank, T., \& Hildred, S. (2004). Rod Stewart: The new biography. London: Portrait.

Eysenck, H. J. (1967). The biological basis of personality. Springfield, IL: Thomas.

Eysenck, H. J. (1988). The biological basis of intelligence. In S. H. Irvine \& J. W. Berry (Eds.), Human abilities in cultural context (pp. 87-104). New York: Cambridge University Press.

Feldman, D. H. (1986). Giftedness as a developmentalist sees it. In R. J. Sternberg \& J. E. Davidson (Eds.), Conceptions of giftedness (pp. 285-305). Cambridge, UK: Cambridge University Press.

Friberg, A. (1991). Generative rules for music performance: a formal description of a rule system, Computer Music Journal, $15,56-71$.

Fox, p. W., Herschberger, S. L., \& Bouchard, T. J., Jr. (1996). Genetic and environmental contributions to the acquisition of a motor skill. Nature, 384, 356-358.
Freeman, J. (1984). Talent in music and Fine Art. Gifted Education International, 2, 107-110.

Gabrielsson, A. (2001). Emotions in strong experiences with music. p. N. Juslin \& J. A. Sloboda (Eds.), Music and emotion. Theory and research (pp. 431-452). Oxford, UK: Oxford University Press.

Gagné, F. (1985). Giftedness and talent: reexamining a reexamination of the definitions. Gifted Child Quarterly, 29(3), 103-112.

Gagné, F. (1999). Nature or nurture? A re-examination of Sloboda and Howe's (1991) interview study. Psychology of Music, 27, 38-51.

Gardner, H. (1983). The Theory of Multiple Intelligences. New York: Basic Books.

Gordon, E. E. (1995). Testing musical aptitudes from preschool through college. In M. Manturzewska, K. Milkaszewski, \& A. Bialkowski (Eds.), Psychology of music today (pp. 170176). Warsaw, Poland: Fryderyk Chopin Academy of Music.

Gregersen, p. K., Kowalsky, E., Kohn, N., \& West-Martin, E. (1999). Absolute pitch: prevalence, ethnic variation, and estimation of the genetic component. American Journal of $\mathrm{Hu}$ man Genetics, 65, 911-913.

Halpern, A. R. (1992). Musical aspects of auditory imagery. In D. Reisberg (Ed.), Auditory imagery (pp. 1-28). Hillsdale, NJ: Lawrence Erlbaum.

Hamlen, W. A. Jr. (1991, November). Superstars in popular music. Empirical evidence. The Review of Economics and Statistics, 73(4), 729-733.

Hallam, S. (1995). Professional musicians' approaches to the learning and interpretation of music. Psychology of Music, 23, 111-128.

Halper, R. (1999). Acting in opera: some humorous and random thoughts. Unpublished essay, available http://users. california.com/ rhalper/ACTING_IN_OPERA.doc [Downloaded November 12, 2006]

Hargreaves, D. J. (1986). The developmental psychology of music. Cambridge, UK: Cambridge University Press.

Harnischmacher, C. (1997). The effects of individual differences in motivation, volition, and maturational processes on practice behavior of young instrumentalists. In H. Jørgensen (Ed.),Does practice make perfect? Current theory and research on instrumental music practice (pp. 71-87). Oslo, Norway: Norges musikkhøgskole.

Haroutounian, J. (2000). Perspectives of musical talent: a study of identification criteria and procedures. High Ability Studies, 11(2), 137-160.

Haroutounian, J. (2002). Musical talent. Kindling the spark: recognizing and developing musical potential. New York: Oxford University Press.

Haskell, H. (1988). The early music revival: a history. London: Thames \& Hudson.

Hassler, M. (1990). Functional cerbral asymmetric and cognitive abilities in musicians, painters, and controls. Brain and Cognition, 13, 1-17.

Hedden, S. K. (1973). Listeners' responses to music in relation to autochtonous and experiential factors. Journal of Research in Music Education, 21, 225-238.

Holmboe, V. (1991). Experiencing music. A composer's notes. London: Toccata Press. 
Hopyan, T., Dennis, M., Weksberg, R., \& Cytrynbaum, C. (2001). Music skills and the expressive interpretation of music in children with Willams-Beuren Syndrome: pitch, rhythm, melodic imagery, phrasing, and musical affect. Child Neuropsychology, 7(1), 42-53.

Howe, M. J. A. (1997). IQ in question. The truth about intelligence. London: Sage.

Howe, M. J. A., Davidson, J. W., \& Sloboda, J. A. (1989). Innate talents: reality of myth? Behavioral and Brain Sciences, 21, 399-442.

Howe, M. J. A., \& Sloboda, J. A. (1991a). Young musicians' accounts of significant influences in their early lives. 1 . The family and the musical background. British Journal of Music Education, 8, 39-52.

Howe, M. J. A., \& Sloboda, J. A. (1991b). Young musicians' accounts of significant influences in their early lives. 2. Teachers, practicing and performing. British Journal of Music Education, 8, 53-63.

Howe, M. J. A., Davidson, J. W., Moore D. G., \& Sloboda, J. A. (1995). Are there early childhood signs of musical ability? Psychology of Music, 23(2), 162-176.

Hunt, E. (1997). Nurture vs. Nature: a feeling of dejá vu. In R. J. Sternberg \& E. Grigorenko (Eds.), Intelligence, heredity, and environment (pp. 531-551). Cambridge, UK: Cambridge University Press.

Huron, D. (2001). Is music an evolutionary adaption? Annals of the New York Academy of Sciences, 930, 43-61.

Illert, M. (1993). Die Motorik des Musizierens [The motor skills of music performance]. In H. Bruhn, R. Oerter, \& H. Rösing (Eds.), Musikpsychologie: Ein Handbuch (pp. 639649). Hamburg, Germany: Rowohlts Encyklopädie.

Juslin, p. N. (2001). Communicating emotion in music performance: a review and a theoretical framework. In p. N. Juslin \& J. A. Sloboda (Eds.), Music and emotion. Theory and research (pp. 309-340). Oxford, UK: Oxford University Press.

Juslin, p. N., \& Sloboda, J. A. (Eds.). (2001). Music and emotion. Theory and research. Oxford, UK: Oxford University Press.

Justus, T., \& Hutsler, J. J. (2005). Fundamental issues in the evolutionary psychology of music. Assessing innateness and domain specificity. Music Perception, 23(1), 1-27.

Kalmus, H., \& Fry, D. B. (1980). On tune deafness (dysmelodia): frequency, development, genetics and musical background. Annals of Human Genetics, 43, 369-382.

Kavolis, V. (1963). A role theory of artistic interest. The Journal of Social Psychology, 60, 31-37.

Kelly, G. A. (1963). A theory of personality: the psychology of personal constructs. New York: W. W. Norton \& Co.

Kemp, A. E. (1996). The musical temperament. Psychology and personality of musicians. Oxford, UK. Oxford University Press.

Kennedy, N. (1991). Always playing. London: Weidenfeld and Nicolson.

Kenny, B. J., \& Gellrich, M. (2002). Improvisation. In R. Parncutt \& G. E. McPherson (Eds.), The science and psychology of music performance. Creative strategies for teaching and learning (pp. 117-134). New York: Oxford University Press.

Kingsbury, H. (1988). Music, talent, and performance: a conservatory system. Philadelphia, PA: Temple University Press.

Kivy, p. A., \& Ky, p. (2002). The possessor and the possessed: Handl, Mozart, Beethoven, and the idea of musical genius. New Haven, CT: Yale University Press.
Klein, p. (1991). Intelligence. The psychometric view. London: Routledge.

Kleinen, G. (1997). Die biographische Dimension musikalischer Begabumh. Jazz und Rockmusik als Untersuchingsgebiet [The biographical dimension of musical giftedness. Studying Jazz and Rock music]. In H. Gembris, R. D. Kraemer, \& G. Maas (Eds.), Musikpädagogische Forschungsberichte 1996. Singen als Gegenstand der Grundlageforschung (pp. 257266). Augsburg, Germany: Wissner Verlag.

Kleinen, G. (2002). Creativity beyond the classical hemisphere. In M. Britta \& M. Mélen (Eds.), La créativité musical - Musical creativity (pp. 1-12). Liége, Belgium: ESCOM.

Koelsch, S., Tomas, G., \& Friederici, A. D. (2000). Brain indices of music processing: "nonmusicians" are musical. Journal of Cognitive Neuroscience, 12(3), 520-541.

Krampe, R. T., \& Ericsson, K. A. (1996). Maintaining excellence: deliberate practice and elite performance in young and older pianists. Journal of Experimental Psychology: General, 124(4), 331-359.

Kyllonen, p. C. (1996). Is working memory capacity Spearman's g? In I. Dennis \& p. Tapsfield (Eds.), Human abilities. Their nature and measurement (pp. 49-75). Mahwah, NJ: Erlbaum.

Lamp, C. J., \& Keys, N. (1932). Can aptitude for specific musical instruments be predicted? The Journal of Educational Psychology, 26, 587-596.

Levitin, D. J. (2000, Fall). In search of the musical mind. Cerebrum: The DANA Forum on Brain Sciences, 2(4), 31-49.

Levitin, D. J., Cole, K., Chiles, M., Lai, Z., Lincoln, A., \& Bellugi, U. (2004). Characterizing the musical phenotype in individuals with Williams Syndrome. Child Neuropsychology, 10(4), 223-247.

Lubart, T., \& Guignard, J. H. (2004). The generality-specificity of creativity: a multivariate approach. In R. J. Sternberg, E. L. Grigorenko, \& J. L. Singer (Eds.), Creativity. From potential to realization (pp. 43-56). Washington, DC: American Psychological Association.

Machotka, p. (1982). Esthetic judgment warm and cool: cognitive and affective determinants. Journal of Personality and Social Psychology, 42(1), 100-107.

Mallia, P., \& ten Have, H. (2005). Pragmatic approaches to genetic screening. Medicine, Health Care, and Philosophy, 8 , 69-77.

Manturzewska, M. (1990). A biographical study of the life span development of professional musicians. Psychology of $\mathrm{Mu}$ sic, 18, 112-139.

Marchant-Haycox, S. E., \& Wilson, G. D. (1992). Personality and stress in performing artists. Personality and Individual Differences, 13, 1061-1068.

Martin, L. (2006, 17 January). "It's going to be a very strong season, I think": An interview with American Idol producer Nigel Lythgoe. Reality News Online. http:// http://www.realitynewsonline.com/cgi-bin/ae.pl? mode $=4 \&$ article $=$ article 9455 .art\&page $=1$ [Viewed 06/11/3]

McArdle, W. D., Katch, F. I., \& Katch, V. L. (2001). Exercise physiology (5th ed.). Philadelphia, PA: Lippincott Williams \& Wilkins.

McKelvie, P., \& Low, J. (2002). Listening to Mozart does not improve children's spatial ability: Final curtains for the Mozart effect. British Journal of Developmental Psychology, 20, 241-258. 
Merriam, A. p. (1964). The anthropology of music. Chicago, IL: Northwestern University Press.

Miah, A. \& Rich, E. (2006). Genetic tests for ability? Talent identification and the value of an open future. Sport, Education and Society, 11(3), 259-273.

Miller, L. K. (1989). Musical savants. Exceptional skills in the mentally retarded. Hillsdale, NJ: Lawrence Erlbaum.

Miller, G. F. (1998). Mate choice: a cognitive perspective. Trends in Cognitive Sciences, 2, 161-201.

Mills, J. (1985). Gifted instrumentalists: how can we recognize them? British Journal of Music Education, 2(1), 39-49.

Mills, J. (1987). Assessment of solo musical performance: a preliminary study. Bulletin of the Council for Research in Music Education, 91, 119-125.

Murray, T. (1991, January). Ethical issues in human genome research. The FASEB Journal, 5, 55-60.

Nagel, J. J. (1993). Stage fright in musicians. A psychodynamic perspective. Bulletin of the Menninger Clinic, 57(4), 492-503.

Nass, M. L. (1975). On hearing and inspiration in the composition of music. Psychoanalytic Quarterly, 44, 431-449.

Noice, T., \& Noice, H. (2002). The expertise of professional actors: a review of recent research. High Ability Studies, 13(1), 7-20.

Noy, p. (1968). The development of musical ability. The Psychoanalytic Study of the Child, 93, 332-347.

Oerter, R. (2003). Biological and psychological correlates of exceptional performance in development. Annals of the New York Academy of Science, 999, 451-460.

O’Neil, S. A., \& McPherson, G. E. (2002). Motivation. In R. Parncutt \& G. E. McPherson (Eds.), The science and psychology of music performance. Creative strategies for teaching and learning (pp. 31-46). New York: Oxford University Press.

Ostwald, P., \& Avery, M. (1991). Psychiatric problems of performing artists. In R. T. Sataloff, A. Brandfonbrenner, \& R. Lederman (Eds.), Textbook of performing arts medicine (pp. 319-335). New York: Raven Press.

Palmer, C., \& Meyer, R. K. (2000). Conceptual and motor learning in music performance. Psychological Science, 11, 63-68.

Peretz, I. (2001). Listen to the brain: a biological perspective on musical emotions. In p. N. Juslin \& J. A. Sloboda (Eds.), Music and emotion. Theory and research (pp. 106-134). Oxford, UK: Oxford University Press.

Peretz, I., Ayotte, J., Zatorre, R. J., Mehler, J., Ahad, P., Penhune, V. B., \& Jutras, B. (2002). Congenital amusia. A disorder of fine-grained pitch discrimination. Neuron, 33(2), 185-191.

Persson, R. S., Pratt, G., \& Robson, C. (1992). Motivational and influential components of musical performance: a qualitative analysis. European Journal for High Ability, 3, 206-217.

Persson, R. S. (1993). The subjectivity of musical performance. An exploratory music-psychological real world enquiry into the determinants and education of musical reality (Doctoral dissertation, School of Human and Health Sciences, University of Huddersfield). Boston Spa, Wetherby, UK: The British Library Document Supply Centre.

Persson, R. S. (1995). Psychosocial stressors among student musicians: a naturalistic study of the teacher-student relationship. International Journal of Arts Medicine, IV(2), $7-13$.
Persson, R. S. (2000). Survival of the fittest or the most talented? Deconstructing the myth of the musical maestro. The Journal of Secondary Gifted Education, 12(1), 25-38.

Persson, R. S. (2001). The subjective world of the performer. In p. N. Juslin \& J. A. Sloboda (Eds.), Music and emotion. Theory and research (pp. 275-290). Oxford, UK: Oxford University Press.

Persson, R. S. (2004). Learning a musical instrument. Creativity or tradition? Education Today, 54(4), 4-7.

Persson, R. S. (2006). The social function of giftedness. Proposing a socio-biological taxonomy. Manuscript submitted for publication.

Phyland, D. J., Oates, J., \& Greenwood, K. M. (1999). Selfreported voice problems among three groups of professional singers. Journal of Voice, 13(4), 602-611.

Piirto, J. (1992). Understanding those who create. Dayton, OH: Ohio Psychology Press.

Polony, L. (1995). Krystian Zimerman's reproductive art. In M. Manturzewska, K. Miklaszewski, \& A. Bialkowski (Eds.), Psychology of music today (pp. 295-302). Warsaw, Poland: Fryderyk Chopin Academy of Music.

Pressing, J. (1988). Improvisation: methods and models. In J. A. Sloboda (Ed.), Generative processes in music. The psychology of performance, improvisation, and composition (pp. 129-178). Oxford, UK: Oxford University Press.

Rauscher, F. H., Shaw, G. L., \& Ky, K. N. (1993). Music and spatial task performance, Nature, 365, 61.

Redfield-Jamison, K. (1993). Touched with fire. Manicdepressive illness and the artistic temperament. New York: The Free Press.

Revesz, G. (1925). The psychology of a musical prodigy. New York: Harcourt Brace.

Revesz, G. (1953). Introduction to the psychology of music. London: Longmans Green.

Ritzer, G. (1992). The McDonaldization of Society. Thousand Oaks, CA: Pine Forge Press.

Roberts, B. A. (1990). Social construction of talent by Canadian university music education majors. Canadian Music Educator, 32(3), 62-73.

Rosen, S. (1981, December). The economics of superstars. American Economic Review, 71, 845-858.

Rothenberg, A. (1990). Creativity and madness. New findings and old stereotypes. Baltimore, MD: Johns Hopkins University Press.

Rovics, H. (1984). Musical development through personal growth. Music Therapy, 4(1), 39-46.

Rouget, G. (1985). Music and trance. A theory of the relationship between music and possession. Chicago: The University of Chicago Press.

Rosenbrock, A. (2003). Creativity with a large $C$ and creativity with a small $c$. Paper given at the Fifth Triennial ESCOM Conference, 8-13 September, Hanover, Germany.

Seashore, C. E. (1919). The psychology of musical talent. New York: McGraw-Hill.

Seashore, C. E. (1938). Psychology of Music. New York: Dover Books.

Segerstråle, U. (2000). Defenders of the truth. The battle for science in the sociobiology debate and beyond. New York: Oxford University Press.

Shafer, L. H. (1976). Intention and performance. Psychological Review, 83(5), 375-393. 
Shuter-Dyson, R., \& Gabriel, C. (1981). The psychology of musical ability. London: Methuen.

Shuter-Dyson, R. (1982). Musical ability, In D. Deutsch (Ed.), The psychology of music (pp. 391-408). San Diego, CA: Academic Press, Inc.

Simon, H. A., \& Chase, W. G. (1973). Skill in chess. American Scientist, 61, 394-403.

Simonton, D. K. (1989). The swan-song phenomenon. Lastworks effects for 172 Classical composers. Psychology and Aging, 4(1), 42-47.

Simonton, D. K. (1992). The social context of career success and course for 2026 scientists and inventors. Personality and Social Psychology Bulletin, 18, 452-463.

Simonton, D. K. (1999). Talent and its development. Psychological Review, 106, 435-457.

Simonton, D. K. (2001). Emotion and composition in Classical music: historiometric perspectives. In p. N. Juslin \& J. A. Sloboda (Eds.), Music and emotion. Theory and research (pp. 205-222). Oxford, UK: Oxford University Press.

Sloboda, J. A. (1985). The musical mind. The cognitive psychology of music. Oxford, UK: Clarendon Press.

Sloboda, J. A. (1991). Musical expertise. In K. A. Ericsson \& J. Smith (Eds.), Toward a general theory of expertise. Prospects and limits (pp. 153-171). Cambridge, UK: Cambridge University Press.

Sloboda, J. A. (2000). Individual differences in music performance. Trends in Cognitive Sciences, 4(10), 397-403.

Sloboda, J. A., \& Howe, M. J. A. (1991). Biographical precursors of musical excellence. An interview study. Psychology of Music, 19(1), 3-21.

Sloboda, J. A., \& Howe, M. J. A. (1999). Musical talent and individual differences in musical achievement. A reply to Gagné. Psychology of Music, 27, 52-54.

Sloboda, J. A., Davidson, J. W., \& Howe, M. J. A. (1994, August). Is everyone musical? The Psychologist, 349-354.

Sosniak, L. A. (1985). Learning to be a concert pianist. In B. S. Bloom (Ed.), Developing talent in young people (pp. 19-67). New York: Ballantine Books.

St Michael, M. (2004). Madonna talking. London: Omnibus Press.

Steele, K. M., Bass, K. E., \& Crook, M. D. (1999). The mystery of the Mozart effect: Failure to replicate. Psychological Science, 10(4), 366-369.

Stelmach, G. E. (1982). Motor control and motor learning: the closed-loop perspective. In J. A. Scott-Kelso (Ed.), Human motor behavior. An introduction (pp. 93-115). Hillsdale, NJ: Lawrence Erlbaum.

Sternberg, R. J. (1988). The triarchic mind. A new theory of human intelligence. New York: Penguin Books.

Sternberg, R. J. (2000). Giftedness as developing expertise. In K. A. Heller, F. J. Mönks, R. J. Sternberg, \& R. F. Subotnik (Eds.), International handbook of giftedness and talent (2nd ed., pp. 55-66). Oxford, UK: Pergamon.

Sternberg, R. J., \& Kolligian, Jr., J. (Eds.). (1990). Competence considered. London: Yale University Press.

Sternberg, R. J., Forsythe, G. B., Hedlund, J., Horvath, J. A., Wagner, R. K., Williams, W. M., et al. (2000). Practical intelligence in everyday life. Cambridge, MA: Cambridge University Press.

Stewart, L., \& Walsh, V. (2002). Congenital amusia: all the songs sound the same. Current Biology, 12, R420-R421.
Storr, A. (1972). The dynamics of creation. London: Penguin Books.

Storr, A. (1992). Music and the Mind. London: HarperCollins Publishers.

Strunk, O. (1965). Source readings in music history. 1. Antiquity and the Middle Ages. London: Faber \& Faber.

Subotnik, R. F. (2000). Developing young adolescent performers at Juilliard: an educational prototype for elite level talent development in the arts and sciences. In. C. F. Van Lieshout \& p. G. Heymans (Eds.), Talent, resilience, and wisdom across the life span (pp. 249-276). Hove, UK: Psychology Press.

Subotnik, R. F. (2003). Adolscent pathways to eminence in Science: Lessons from the music conservatory. In p. Csermely \& L. Lederman (Eds.), Science education, talent recruitment, and public understanding (pp. 295-304). New York: IOS Press.

Subotnik, R. F., Jarvin, L., Moga, E., \& Sternberg, R. J. (2004) Wisdom from gate-keepers: secrets of success in music performance. Bulletin of Psychology and the Arts, 4(2), $1-7$.

Sundberg, J. (1987). The science of the singing voice. San Diego, CA: Singular Publishing Group.

Sundberg, J. (1988). Computer synthesis of music performance. In J. A. Sloboda (Ed.), Generative processes in music. The psychology of performance, improvisation, and composition (pp. 52-69). Oxford, UK: Oxford University Press.

Tart, C. T. (Ed.). (1990). Altered states of consciousness (3rd ed.). San Fransisco, CA: Harper.

Tervaniemi, M. (2001). Musical sound processing in the human brain. Evidence from electric and magnetic recordings. Annals of the New York Academy of Sciences, 930, 259-272.

Thompson, L. A., \& Plomin, R. (1993). Genetic influence on cognitive ability. In K. A. Heller, F. J. Mönks, \& A. Harry Passow (Eds.), International handbook of research and development of giftedness and talent (pp. 103-114). Oxford, UK: Pergamon.

Thompson, W., \& Waterman, F. (1990). Piano competition: The story of The Leed's. London: Faber \& Faber.

Tomatis, A. (1991). Pourquoi Mozart? [Why Mozart?]. Paris: Editions Fixot.

Triandis, H. C. (1990). Theoretical concepts that are applicable to the analysis of ethnocentrism. In R. W. Brislin (Ed.), Applied cross-cultural psychology (pp. 34-55). London: Sage.

Trost, G. (2000). Prediction of excellence in school, higher education, and work. In K. A. Heller, F. J. Mönks, R. J. Sternberg, $\&$ R. F. Subotnik (Eds.), International handbook of giftedness and talent (2nd ed., pp. 317-330). Oxford, UK: Pergamon.

Unkefer, R. F. (Ed.). (1990). Music therapy in the treatment of adults with mental disorders. Theoretical bases and clinical interventions. New York: Schirmer Books.

Van Rossum, J. H. A. (2001). Talented in dance: the Bloom Stage Model revisited in the personal histories of dance students. High Ability Studies, 12(1), 181-198.

Wing, H. D. (1941). A factorial study of musical tests. British Journal of Psychology, 31, 341-355.

Winner, E. (2000). The origins and ends of giftedness. American Psychologist, 55(1), 159-169.

Winner, E., \& Hetland, L. (2000). Introduction. The arts in education: Evaluating the evidence for a causal link. Journal of Aesthetic Education, 34(3-4), 3-10. 
Winner, E., \& Hetland, L. (2001). The arts and academic achievement: What the evidence shows. Arts Education Policy Review, 102(5), 3-6.

Winner, E., \& Martino, G. (2000). Giftedness in non-academic domains: the case of visual arts and music. In K. A. Heller, F. J. Mönks, R. J. Sternberg, \& R. F. Subotnik (Eds.), International handbook of giftedness and talent (2nd ed., pp. 95110). Oxford, UK: Pergamon.

Wright, A., Rivera, J. J., Hulse, S. H., Shyan, M., \& Neiworth, J. J. (2000). Music perception and octave generalization in Rhe- sus monkeys. Journal of Experimental Psychology: General, 129(3), 291-307.

Ziegler, A., \& Raul, T. (2000). Myth and reality: a review of empirical studies on giftedness. High Ability Studies, 11(2), 114-136.

Zuckerkandl, V. (1973). Man the musician. Chicago, IL: Chicago University Press. 
Book_Shavinina_9781402061615_Proof2_December 2, 2008

01

02

03

04

05

06

07

08

09

10

11

12

13

14

15

16

17

18

19

20

21

22

23

24

25

26

27

28

29

30

31

32

33

34

35

36

37

38

39

40 